\title{
The Development of Legal Protection for Mediation Confidentiality in Hong Kong
}

\author{
A.K.C. Koo* and Yun Zhao ${ }^{\dagger}$
}

\begin{abstract}
One of the underlying objectives of the reformed civil justice system in Hong Kong is to facilitate the settlement of disputes. The court is now under the duty of active case management to encourage and promote the use of an alternative dispute resolution procedure where appropriate. Facilitative mediation was generally practised in Hong Kong before the Civil Justice Reform. By issuing a specific practice direction on mediation, the judiciary has given a strong boost for this process to the extent that parties may even be penalized in costs if they unreasonably refuse to mediate. The continuous transfer of conflict resolution from the hands of the judge to the parties gives rise to an increasing risk that information disclosed in mediation may be used to the parties' disadvantage in subsequent legal proceedings. This paper examines the precise scope of three common law principles that protect confidentiality of mediation communications. Drawing upon the approaches of local institutions, the US Uniform Mediation Act and the EU Mediation Directive, it considers the arguments that might be relevant in deciding what law should govern the issues at present not covered by the existing legal framework, a question that has become more pressing in view of the fact that negotiations have begun on a proposed mediation ordinance to deal with it.
\end{abstract}

Keywords: confidentiality; Hong Kong; legal professional privilege; legislation on mediation; mediation; without prejudice communications

\section{Introduction}

Facilitative mediation is one important alternative dispute resolution mechanism. It provides a timely and flexible means to resolve various types of disputes in daily life. Unlike negotiation, a neutral third party clarifies and enhances communications between the disputants; unlike arbitration, the mediator in no way acts as referee in the dispute. The principal role of a facilitative mediator is to structure a co-

* A.K.C. Koo, Assistant Professor, Department of Law, University of Hong Kong; e-mail: akckoo@hku.hk

+ Yun Zhao, Associate Professor, Department of Law, University of Hong Kong. The paper is fully supported by a research grant from the Research Grants Council of the Hong Kong Special Administrative Region, China (Project No. 755109). 
operative, interest-based process for the purpose of assisting the disputing parties to reach a mutually agreed settlement. Skilled mediators enable the parties to give vent to their feelings and direct them to rational discussions, which is believed to be essential to maintain an ongoing inter-party relationship. As such, Chinese societies have strong cultural traditions for mediation, emphasizing the Confucian doctrine of the meaning and concept of harmony. Over the past two decades, various common law jurisdictions attached greater importance to mediation in the civil justice system.

In Hong Kong, mediation has become part of the court's process since the implementation of the Civil Justice Reform in April 2009. An underlying objective of the reformed civil justice system is to facilitate the settlement of disputes. ${ }^{1}$ The court is now under the duty of active case management to encourage and promote the use of an alternative dispute resolution procedure where appropriate. ${ }^{2}$ Of all the various non-litigious methods to resolve disputes, the judiciary gave prominence to mediation. ${ }^{3}$ One of the most oft-cited benefits of mediation is confidentiality in the process, which allows the parties to freely exchange their needs and explore creative solutions to problems. Widely recognized as vital to the prospects of settlement, the common law has long afforded protection for confidentiality in all types of settlement negotiations. But the current legal framework does not distinctly define the contents and scope of mediation confidentiality. As Hong Kong is at the moment considering legislation on mediation, it is time to understand why a mediation ordinance is needed and how it can provide greater certainty for confidentiality of mediation communications.

This paper will first explain the implications of confidentiality to the mediation process, mediation participants and mediators. It will then analyse different sources of mediation confidentiality recognized at common law. After exploring the practical limits of the existing legal framework, it will evaluate local institutional efforts to promote the concept of mediation confidentiality. The paper will conclude with discussions on the role of future mediation legislation in Hong Kong.

\section{Legal Protection for Mediation Confidentiality}

Confidentiality is regarded as an important philosophical tenet of mediation. ${ }^{4}$ It offers a private negotiating sphere for mediation participants to come to an agreement of their own. A secure process controlled by a neutral mediator dispels the fear that what passed in

1 Rules of the High Court (Cap 4A), O. 1A, r. 1(e).

2 Ibid., O. 1A, r. 4(1), (2)(e).

3 The Judiciary of the Hong Kong Special Administrative Region, 'Practice Direction 31: Mediation' (12 February 2009).

4 David Spencer and Michael Brogan, Mediation Law and Practice (Cambridge University Press: Melbourne, 2006) 312. 
mediation may be used against the parties in subsequent proceedings. This helps build mutual trust between the parties, so that they would participate in open and frank settlement negotiations in good faith. Confidentiality is not only beneficial to the parties, but also the mediators. Being exempted from giving evidence and producing record notes in the court, mediators can concentrate on the process, mediation soft skills and the needs of the parties in each case.

In this paper, the word 'confidentiality' is an umbrella term describing the status of communications made in mediation. It encompasses three distinct concepts at common law: contractual or implied obligations of confidentiality, legal professional privilege and the without prejudice rule. It is useful to examine these concepts in turn and determine how far they give rights to or impose obligations on mediation participants and mediators not to divulge communications made in the process to third parties.

\section{i. Contractual or Implied Obligations of Confidentiality}

Generally, mediation participants and the mediator sign a written agreement before mediation begins. A typical mediation agreement sets out express obligations of confidentiality between the participants, between any of them and the mediator, and on the mediator. ${ }^{5}$ Participants are required not to rely on or disclose to any other person all information produced for, arising out of, or in connection with the mediation in subsequent proceedings concerning the dispute. They will not call the mediator as a witness, or demand the mediator to produce record notes, in those proceedings. Mediators also have both general and specific obligations. The mediator will not reveal anything discussed in the mediation unless permitted by all parties or compelled by law to do so. In addition, the mediator will not disclose the communications made in separate meetings with either party except with that party's consent. Absent such an express contractual provision, a similar duty of confidentiality would arise in the context of mediation by implication or in equity. ${ }^{6}$

Yet a duty of confidentiality is not an absolute bar to disclosure in legal proceedings. ${ }^{7}$ The court will compel disclosure of all relevant information needed for the fair disposal of a case. ${ }^{8}$ Ramsey $\mathrm{J}$ in Farm

5 See, for example, Law Society of Hong Kong, 'Mediation Rules', r. 12; Law Society of Hong Kong, 'Sample Mediation Agreement', cl. 6; Hong Kong International Arbitration Centre, 'Mediation Rules', rr. 12, 14; Hong Kong International Arbitration Centre, 'Agreement to Mediate', cl. 5.

6 R.G. Toulson and C.M. Phipps, Confidentiality, 2nd edn (Sweet \& Maxwell: London, 2006) para. 15-016.

7 Paragon Finance Plc (formerly National Home Loans Corporation Plc) v Freshfields (a firm) [1999] 1 WLR 1183 at 1188, CA.

8 Three Rivers DC v Governor and Company of the Bank of England (No. 4) [2004] UKHL 48; [2005] 1 AC 610 [28]. 
Assist Ltd (In Liquidation) v Secretary of State for the Environment, Food and Rural Affairs ${ }^{9}$ summarized the principles as follows:

The proceedings are confidential both as between the parties and as between the parties and the mediator. As a result even if the parties agree that matters can be referred to outside the mediation, the mediator can enforce the confidentiality provision. The court will generally uphold that confidentiality but where it is necessary in the interests of justice for evidence to be given of confidential matters, the Courts will order or permit that evidence to be given or produced.

In that case, the court refused the mediator's application to set aside her witness summons. The contractual and implied duty of confidentiality yielded to the interests of the administration of justice in receiving her testimonial evidence, so that the court could determine whether economic duress invalidated the concluded compromise between the parties.

\section{ii. Legal Professional Privilege}

It is common for a mediation party to show the mediator a letter of legal advice ${ }^{10}$ or a document brought into existence for the dominant purpose of a contemplated or pending litigation ${ }^{11}$ in separate meetings. That party can assert legal professional privilege and refuse to disclose such confidential communications in subsequent proceedings. Lord Scott of Foscote in Three Rivers DC $\mathrm{v}$ Bank of England (No. 6) ${ }^{12}$ explained the scope of the privilege:

[I] a communication or document qualifies for legal professional privilege, the privilege is absolute. It cannot be overridden by some supposedly greater public interest. It can be waived by the person, the client, entitled to it and it can be overridden by statute, but it is otherwise absolute. There is no balancing exercise that has to be carried out.

An apparent exception is where the client and its legal adviser have abused their confidential relationship to facilitate crime or fraud. ${ }^{13}$

Sharing a privileged communication with the mediator does not constitute a waiver. Therefore, the right to assert legal professional privilege remains. ${ }^{14}$ To hold otherwise would set unnecessary limits to the ability of mediators to receive mediation secrets from each party and use them to bring about settlements.

9 Farm Assist Ltd (In Liquidation) v Secretary of State for the Environment, Food and Rural Affairs [2009] EWHC 1102, TCC, para. 44.

10 Greenough v Gaskell [1824-34] All ER 767.

11 Balabel v Air India [1988] Ch 317; Three Rivers District Council v Bank of England (Disclosure) (No. 5) [2003] EWCA Civ 474; [2003] QB 1556; Three Rivers DC, above n. 8.

12 Three Rivers DC v Bank of England (No. 6) [2005] 1 AC 610 at 646.

13 Paragon Finance, above n. 7 at 1188.

14 Farm Assist, above n. 9 at para. 44. 


\section{iii. The Without Prejudice Rule}

Even before litigation became excessively complex and costly, the common law had adopted the without prejudice rule to promote settlement out of court. ${ }^{15}$ The aim of the rule is to free opposing parties of the fear that what they say during settlement negotiations could be used to their disadvantage in subsequent legal proceedings. It renders communications made in aid of settlement both inadmissible in evidence and immune from disclosure. The protection covers statements made by the parties ${ }^{16}$ and those obtained from third parties $^{17}$ automatically, ${ }^{18}$ provided that they form part of a genuine attempt to arrive at an agreed resolution. ${ }^{19}$ The protection applies to all forms of settlement negotiations, including mediation. ${ }^{20}$

The without prejudice rule is primarily founded on public policy. Oliver LJ in Cutts v Head ${ }^{21}$ remarked:

[T] he rule rests, at least in part, on public policy is clear from many authorities, and the convenient starting point of the inquiry is the nature of the underlying policy. It is that parties should be encouraged so far as possible to settle their disputes without resort to litigation and should not be discouraged by the knowledge that anything that is said in the course of such negotiations (and that includes, of course, as much the failure to reply to an offer as an actual reply) may be used to their prejudice in the course of the proceedings. They should, as it was expressed by Clauson J in Scott Paper Co v Drayton Paper Works Ltd (1927) 44 RPC 151 at 157, be encouraged freely and frankly to put their cards on the table...

Lord Griffiths endorsed this view in Rush \& Tompkins Ltd v Greater London Council ${ }^{22}$ and observed that the rule is founded upon the public policy of encouraging litigants to settle their differences rather than litigate them to a finish'.

Later, Hoffmann LJ (as he then was) in Muller v Linsley \& Mortimer (a firm) ${ }^{23}$ added the second basis of the rule:

Cutts v Head shows that the rule has two justifications. Firstly, the public policy of encouraging parties to negotiate and settle their disputes out of court and, secondly, an implied agreement arising out of what is commonly understood to be the consequences of offering or agreeing to

15 See, for example, Walker v Wilsher (1889) 23 QBD 335.

16 Jackson v Ministry of Defence [2006] EWCA Civ 46.

17 Rabin v Mendoza \& Co [1954] 1 All ER 247.

18 Chocoladefabriken Lindt \& Sprungli AG v Nestlé Co. Ltd [1978] RPC 287; Rush \& Tompkins Ltd v Greater London Council [1989] AC 1280, HL; Bradford \& Bingley Plo v Rashid [2005] EWCA Civ 1080; Jackson, above n. 16.

19 Buckinghamshire County Council v Moran [1990] Ch 623; Parry v News Group Newspapers Ltd [1990] NLJR 1719, CA.

20 Reed Executive Plc v Reed Business Information Ltd [2004] EWCA Civ 887; [2004] 4 All ER 942.

21 Cutts v Head [1984] Ch 290 at 306.

22 Rush \& Tompkins, above n. 18 at 1299.

23 Muller v Linsley and Mortimer (a firm) [1996] 1 PNLR 74 at 77; see also Unilever PlC v Procter \& Gamble Co [2000] 1 WLR 2436 at 2442; Prudential Assurance Co Ltd v Prudential Insurance Co of America (No. 2) [2003] EWCA Civ 1154; [2004] ETMR 29. 
negotiate without prejudice. In some cases both of these justifications are present; in others, only one or the other.

The two justifications are inter-related. The without prejudice rule offers protection for settlement negotiations on grounds of public policy. Once the parties have agreed to negotiate on that basis, considerations of elementary justice dictate that expectations created by the law must not be disappointed by the law. ${ }^{24}$ The rationale behind the rule is not only essential for understanding its purpose, but also useful for determining its extent.

In Muller, Hoffmann LJ took the view that only admissions were protected ${ }^{25}$ Robert Walker LJ (as he then was) in Unilever Plc $\mathrm{v}$ The Procter \& Gamble $\mathrm{Co}^{26}$ emphatically rejected this narrow approach. He warned that dissecting out identifiable admissions and withholding protection from the rest of without prejudice communications would create huge practical difficulties. Further, he pointed out that drawing such a distinction would be contrary to the underlying objective of encouraging the parties to speak freely about all issues in the litigation both factual and legal when seeking compromise and, for the purpose of establishing a basis of compromise, admitting certain facts. These authorities were subjected to an exhaustive review by the House of Lords in its recent decision in Ofulue v Bossert. ${ }^{27}$ Lord Hope of Craighead, with whom Lord Neuberger of Abbotsbury, Lord Rodger of Earlsferry and Lord Walker of Gestingthorpe concurred, approved of Robert Walker LJ's analysis as being consistent with the approach in Rush \& Tompkins and that of the courts in the nineteenth century. ${ }^{28}$ His Lordship agreed that singling out admissions was too subtle to apply in practice. ${ }^{29}$ He observed that Hoffmann LJ's distinction appeared to be limited to the public policy reason for the without prejudice rule and ignored the contractual reason. ${ }^{30}$ His Lordship concluded: ${ }^{31}$

[S]ave perhaps where it is wholly unconnected with the issues between the parties to the proceedings, a statement in without prejudice negotiations should not be admissible in evidence, other than in exceptional circumstances such as those mentioned in the Unilever case [2000] 1 WLR 2436, 2444d-2445g.

24 Adrian Zuckerman, Zuckerman on Civil Procedure: Principles of Practice, 2nd edn (Sweet \& Maxwell: London, 2006) para. 16.5.

25 Muller, above n. 23 at 79.

26 Unilever, above n. 23 at $2448-9$.

27 Ofulue v Bossert [2009] 1 AC 990, HL.

28 Ibid. at 1021.

29 Ibid. at 1023

$30 \mathrm{Ibid}$. at 1023

31 Ibid. at 1022. 
It is clear that although the without prejudice rule is broad in scope, its well-established exceptions could lead to loss of confidentiality in mediation in practice.

\section{Practical Limits of the Current Legal Framework}

As has already been noted, the legal protection for confidentiality in mediation is far from absolute. Express and implied obligations of confidentiality yield to the public interest in the administration of justice. Legal professional privilege is subject to statutory abrogation and the criminal purpose exception. Increasing concerns about parties' conduct in mediation and the fairness of mediated settlements have prompted the courts to lift the without prejudice veil. Robert Walker LJ in the Unilever case ${ }^{32}$ summarized eight of the most important instances. Recent first instance decisions in England and Wales illustrate that these without prejudice exceptions apply equally in the context of mediation, which will be discussed below.

\section{i. Proof of a Settlement Agreement}

Without prejudice communications are admissible to prove whether they have resulted in an agreed settlement. ${ }^{33}$ Danckwerts LJ in Tomlin v Standard Telephones and Cables Ltd ${ }^{34}$ explained that it would be impossible to decide whether there was a concluded compromise or not unless one looked at the contents of the negotiations. It might be the intention of the parties that there was a binding agreement contained in those communications. Alternatively, Hoffmann LJ in the Muller case ${ }^{35}$ held that such communications were relevant because they might constitute the offer and acceptance of a contract that replaced the cause of action previously in dispute. On either basis, proof of a concluded compromise is consistent with the public policy aspect of the without prejudice rule, and thus is not a true exception.

In Brown v Rice \& Patel, ${ }^{36}$ the issue for the court was whether the parties had settled in a mediation that took place shortly before the trial. Stuart Isaacs QC, sitting as a High Court judge, held that exceptions to the without prejudice rule applied to mediation despite the fact that it is a form of assisted without prejudice negotiation. ${ }^{37}$ The judge admitted into evidence the mediator's manuscript, his correspondence to the parties, and testimonial evidence of what the parties had said and done in the mediation. Nonetheless, he found that the second respondent's offer to settle did not deal with the manner of

32 Unilever, above n. 23 at $2444-5$.

33 Tomlin $\vee$ Standard Telephones and Cables Ltd [1969] 1 WLR 1378; [1969] 3 All ER 201.

34 Ibid. at $1382-3$.

35 Muller, above n. 23 at $79-80$.

36 Brown v Rice \& Patel [2007] EWHC 625, Ch; [2008] FSR 3.

37 Ibid. at paras $15,21$. 
disposal of the litigation. For this reason, the offer was incomplete and incapable of being accepted to form an agreed settlement.

\section{ii. Estoppel}

Where, even if there is no concluded compromise, a party made a clear and unambiguous statement with the intention that the other party to the without prejudice negotiations would rely on it and in fact did so, that other party may adduce the statement as evidence and raise an estoppel. ${ }^{38}$ Neuberger $\mathrm{J}$ in Hodgkinson \& Corby Ltd v Wards Mobility Services Ltd (No. 2) ${ }^{39}$ reasoned that it would be plainly unconscionable to allow the first party to hide behind the cloak of without prejudice. Furthermore, it was consistent with the exception of proving the existence of a settlement agreement. ${ }^{40}$

Such an issue arose in the Brown case. ${ }^{41}$ The second respondent made an oral offer to settle during a mediation. The applicant purportedly accepted the offer by fax within the acceptance period. But an express term in the mediation agreement required that any settlement agreement must be in writing and signed by or on behalf of all parties. The applicant argued that giving effect to the express term would deprive the acceptance period of any meaning. The argument was one of estoppel, although the applicant relied on an implied waiver of the term instead. Stuart Isaacs QC rejected both grounds, holding that the express term dealt with the form of a settlement agreement, not whether there was a settlement at all. Thus, it could not render the existence of the acceptance period otiose.

\section{iii. Proof of a Vitiating Factor}

Evidence of without prejudice negotiations is admissible to show that a settlement agreement should be set aside on grounds of misrepresentation, fraud or undue influence. ${ }^{42}$ In Ruttle Plant Hire Ltd v Secretary of State for the Environment, Food and Rural Affairs ${ }^{43}$ and the Farm Assist case, ${ }^{44}$ each claimant sought to set aside a mediated settlement for economic duress. Ramsey $\mathrm{J}$ refused to strike out the claim in Ruttle Plant and declined to set aside a witness summons for the mediator in Farm Assist. The judge was right in reaching these conclusions, as justice requires the court to find out and disapprove settlement agreements that were unfairly entered into.

38 Hodgkinson \& Corby Ltd v Wards Mobility Services Ltd (No. 2) [1997] FSR 178 at 190-1, reversed in [1998] FSR 530, CA, but not disapproved on this point on appeal.

39 Hodgkinson \& Corby, above n. 38 at 190-1.

40 Ibid. at 191.

41 Brown, above n. 36.

42 Underwood v Cox (1912) 4 DLR 66.

43 Ruttle Plant Hire Ltd v Secretary of State for the Environment, Food and Rural Affairs [2007] EWHC 2870, TCC; [2008] 2 All ER (Comm) 264.

44 Farm Assist, above n. 9. 


\section{iv. Proof of Unambiguous Impropriety}

The court may look at evidence of without prejudice negotiations if its exclusion would act as a cloak for perjury, blackmail or other unambiguous impropriety. ${ }^{45}$ This exception targets a clear case of abuse of the rule's protection. ${ }^{46}$ Rix LJ in Savings \& Investment Bank Ltd (In Liquidation) $v$ Fincken ${ }^{47}$ reiterated that the public interest in the without prejudice rule was not to be sacrificed save in truly exceptional and needy circumstances.

The narrow scope of this exception is illustrated in Venture Investment Placement Ltd $\mathrm{v}$ Hall $^{48}$ In that case, the claimant sought an interim injunction restraining the defendant from disclosing to any third parties what was said in the mediation. Deputy Judge Reid QC granted the application and held that the defendant could not rely on the unambiguous impropriety exception because there was a serious question to be tried as to whether anything said in the mediation could amount to impropriety.

\section{v. Explaining Delay in Proceedings}

Without prejudice communications are admissible to explain delay in the proceedings or a party's apparent acquiescence to such delay. ${ }^{49}$ Lindley LJ in Walker $v$ Wilsher ${ }^{50}$ noted that the court could take into account the existence of without prejudice communications and when they were made. But Robert Walker LJ in the Unilever case ${ }^{51}$ observed that the court might refer to fuller evidence in order to have a fair picture of the rights and wrongs of the delay. In practice, this exception becomes less significant where the parties entered into settlement negotiations on the basis of 'without prejudice save as to costs'.

\section{vi. Without Prejudice Save as to Costs}

The parties can vary the application of the without prejudice rule on matters passing in settlement negotiations by agreement. ${ }^{52}$ A good example is settlement communications made 'without prejudice except as to costs' ${ }^{53}$ In the absence of such a negotiating basis, the court

45 Forster v Friedland [1992] CA Transcript 1052; Finch v Wilson (8 May 1987, unreported); Hawick Jersey Intemational v Caplan, The Times, 11 March 1988.

46 Forster, above n. 45; see also Fazil-Alizadeh v Nikbin, The Times, 19 March 1993.

47 Savings \& Investment Bank Ltd (In Liquidation) v Fincken [2003] EWCA Civ 1630; [2004] 1 All ER 1125.

48 Venture Investment Placement Ltd v Hall [2005] EWHC 1227, Ch.

49 Walker, above n. 15 at 338.

50 Ibid.

51 Unilever, above n. 23.

52 Cutts v Head, above n. 21 at 316.

53 Calderbank v Calderbank [1975] 3 All ER 333, reaffirmed in Cutts v Head, above n. 21, and approved in Rush \& Tompkins, above n. 18. 
has no jurisdiction to compel disclosure of without prejudice negotiations, even though that may prevent it from determining the reasonableness of a refusal to participate in mediation. ${ }^{54}$

\section{vii. Establishing Reasonable Conduct}

Where a claimant alleges that it has acted reasonably to mitigate its loss in its conduct and conclusion of settlement negotiations, and then seeks any shortfall from a non-party to the settlement negotiations in legal proceedings, the claimant waives the without prejudice protection over negotiation materials. ${ }^{55}$ Swinton Thomas and Leggatt LJJ in the Muller case ${ }^{56}$ held that the court could compel disclosure of all the documents leading to the settlement on the ground that the claimant had put its conduct in issue and that it would be inequitable not to order discovery.

However, this exception did not apply in the recent case of Cumbria Waste Management Ltd \& Lakeland Waste Management Ltd v Baines Wilson (A Firm). ${ }^{57}$ In that case, the defendant sought to obtain disclosure of documents of a successful mediation between the claimants and a third party, because it was sued for the shortfall between the amount invoiced and the settlement monies due to professional negligence. Her Honour Judge Kirkham, sitting as a High Court judge, recognized that the third party was entitled to resist disclosure: ${ }^{58}$

The circumstances in Muller are different from those which obtain here. In that case, it was the plaintiffs who sought to deny disclosure of without prejudice material. Here, the question is whether a third party's without prejudice material should be disclosed. The Court of Appeal in Muller gave no consideration to the position of a third party. In this case the privilege belongs not only to the claimants but also to DEFRA. There are public policy reasons why DEFRA should be entitled to assert that privilege: DEFRA are entitled to protect from disclosure material which may embarrass them in other disputes.

\section{viii. Matrimonial and Parental Conciliation Privilege}

A distinct privilege has developed by way of analogy with the without prejudice rule in relation to family conciliation. ${ }^{59}$ The privilege, based on the public interest in the stability of marriage, renders negotiations intended to settle matrimonial and parental disputes inadmissible except in the rare case where it is necessary to adduce such evidence for protecting the well-being of a child. ${ }^{60}$

\footnotetext{
54 Reed Executive, above n. 20.

55 Muller, above n. 23.

56 Ibid.

57 Cumbria Waste Management Ltd \& Lakeland Waste Management Ltd v Baines Wilson (A Firm) [2008] EWHC 786, QB

58 Cumbria Waste Management, above n. 57 at para. 24.

59 Re D (Minors) (Conciliation: Disclosure of Information) [1993] Fam 231 at 238.

60 Ibid. at $240-1$.
} 
This development lends support for the recent debate as to the possible existence of mediation privilege and the desirability for a mediator's privilege at common law. ${ }^{61}$ Ramsey J in the Farm Assist Ltd case $^{62}$ said that there was no special privilege attaching to the mediation process or the mediator. Stuart Isaacs QC in the Brown case ${ }^{63}$ left this question to be considered by the legislature or the courts.

\section{Institutional Efforts to Regulate Mediation Confidentiality}

Attempts have been made by major mediation service providers, the judiciary and the government in Hong Kong to regulate mediation confidentiality. The Mediation Rules of the Hong Kong International Arbitration Centre provide:

Confidentiality

12. (i) Mediation is a private and confidential process. Every document, communication or information disclosed, made or produced by any party for the purpose of or related to the mediation process shall be disclosed on a privileged and without prejudice basis and no privilege or confidentiality shall be waived by such disclosure. Confidentiality also extends to the settlement agreement except where its disclosure is necessary for implementation or enforcement.

(ii) Nothing that transpires during the course of the mediation is intended to or shall in any way affect the rights or prejudice the position of the parties to the dispute in any subsequent arbitration, adjudication or litigation.

Mediator's Role in Subsequent Proceedings

14. The parties undertake that the mediator shall not be appointed as adjudicator, arbitrator or representative, counsel or expert witness of any party in any subsequent adjudication, arbitration or judicial proceedings whether arising out of the mediation or any other dispute in connection with the same contract. No party shall be entitled to call the mediator as a witness in any subsequent adjudication, arbitration or judicial proceedings arising out of the same contract.

The Mediation Rules of the Hong Kong Law Society reflect the concept of confidentiality in a similar manner. ${ }^{64}$ In addition, the Law Society's Mediation Rules give a detailed account of the types of

61 Henry Brown and Arthur Marriott QC, ADR: Principles and Practice (Sweet \& Maxwell: London, 1999) paras 22-079 to 22-097.

62 Farm Assist, above n. 9 at para. 43.

63 Brown, above n. 36 at para. 20.

64 Law Society of Hong Kong, 'Mediation Rules', art. 12. 
communications that are inadmissible in any subsequent proceedings $^{65}$ and those that are admissible for enforcing a settlement agreement. ${ }^{66}$ The rules also offer examples demonstrating that communications passed in mediation would not affect the rights or prejudice the position of the parties in subsequent proceedings. ${ }^{67}$

Although the professional rules make reference to mediation confidentiality, they fail to deal with the exact scope and well-established limits of the existing legal framework. The terms 'confidential', 'privileged' and 'without prejudice' are used interchangeably without distinction. Only one apparent exception to the legal protection-the enforcement of mediated settlements-is emphasized. Unless clarified by individual mediators, these mediation rules encourage general members of the public to mediate with a mistaken belief that what they say in the process can never be used against them or disclosed to any third party. This situation is certainly unsatisfactory to the healthy development of alternative dispute resolution processes in Hong Kong.

As an important part of the Civil Justice Reform, the Judiciary of Hong Kong promulgated a practice direction on mediation to assist the courts in discharging the duty of facilitating settlement of disputes. Article 6 of Practice Direction $31^{68}$ states:

In all contexts, including dealing with matters arising under this PD and in exercising its discretion on costs, the Court cannot compel the disclosure of or admit materials so long as they are protected by privilege

65 Article 12(a) of the Hong Kong Law Society's Mediation Rules provides that '[t]he parties shall not rely on or introduce as evidence in any subsequent judicial or arbitral proceedings:- (i) any oral or written exchanges within the mediation made in connection with any mediation conducted under these Rules between a party and the mediator or between any party; (ii) any views expressed or suggestions made within the mediation either by the mediator or a party in respect of a possible settlement of the dispute; (iii) any admission made by a party in connection with any mediation conducted under these Rules; (iv) the fact that a party had or had not indicated a willingness to accept any suggestion or proposal for settlement by the mediator or by any party; and (v) any documents brought into existence for the purpose of the mediation including any notes or records made in connection with any mediation conducted under these Rules by the mediator or a party.'

66 Article 12(a) of the Hong Kong Law Society's Mediation Rules provides that ... when any party enforces a settlement agreement any party may call evidence of the settlement agreement including evidence from the mediator and any other person engaged in the mediation.'

67 Article 12(b) of the Hong Kong Law Society's Mediation Rules lists the following two examples: '(i) the fact that information of whatsoever nature was available to the mediator does not mean that privilege or confidentiality is waived for any subsequent litigation, arbitration or adjudication; and (ii) the fact that the accuracy of information or the validity or meaning of documents was not challenged during the mediation does not preclude challenge in subsequent litigation, arbitration or adjudication.'

68 Practice Direction 31: Mediation, above n. 3. 
in accordance with legal principles, including legal professional privilege and the privilege protecting without prejudice communications. What happens during the mediation process, being without prejudice communications, is protected by privilege. It must be emphasized that there is no question of the Court undermining the protection afforded by privilege.

It is clear that the practice direction displays weaknesses similar to those of the professional rules.

In February 2010, the Department of Justice of the Hong Kong Government published a report of its Working Group on Mediation. The Working Group reviewed many important issues that are fundamental to the more effective and extensive application of mediation in both commercial and community disputes. It recommended that a new stand-alone ${ }^{69}$ mediation ordinance be enacted ${ }^{70}$ with an aim to providing a proper legislative framework for the conduct of mediation. ${ }^{71}$ The proposed legislation represents the government's approval of mediation as a legitimate means of alternative dispute resolution, which, in turn, will promote its use to the general public and the legal profession. ${ }^{72}$

Acknowledging that uncertainty exists in the common law principles governing mediation confidentiality, ${ }^{73}$ the Working Group made a recommendation that the proposed ordinance should deal with the general rules of confidentiality, exceptions to the rules and sanctions for breaches. ${ }^{74}$ Codification of the existing legal framework would no doubt promote generality and clarity. The legal principles and well-established exceptions discussed in the previous sections deserve a place in the new legislation. Sadly the Working Group appeared conservative as to how the proposed ordinance can provide greater protection for mediation confidentiality. While a statutory right for mediation participants and mediators to seek an injunction to restrain unauthorized use of confidential materials is under consideration, ${ }^{75}$ the Working Group was silent as to whether there should be a privilege specific to mediation. It is not helpful to have a cursory look at the legislation in selected jurisdictions; ${ }^{76}$ only two of them enacted a mediation privilege and took different approaches.

69 Department of Justice of the Government of the Hong Kong Special Administrative Region, 'Report of the Working Group on Mediation' (February 2010) paras 7.27-7.37.

70 Ibid., Recommendation 32.

$71 \mathrm{lbid}$. at paras $7.19-7.21$.

72 lbid. at paras $7.22-7.25$.

$73 \mathrm{Ibid}$. at paras $7.132-7.133$.

$74 \mathrm{Ibid}$. at para. 7.128; Recommendation 38.

75 Ibid. at para. 7.138 .

$76 \mathrm{Ibid}$, at paras $7.124-7.127$. 
The United States Uniform Mediation $\mathrm{Act}^{77}$ creates a mediation communication privilege. The privilege covers communications made to initiate and participate in a mediation, ${ }^{78}$ founded on the empirical assumption that it is essential for promoting candour of parties and public confidence and for balancing the interests of justice against the private need for confidentiality. ${ }^{79}$ Privileged communications are immune from disclosure and inadmissible ${ }^{80}$ in subsequent court proceedings or other adjudicative processes. ${ }^{81}$ Both mediators and mediation parties are eligible to assert the privilege attached to a mediation communication. ${ }^{82}$ In addition, mediators and non-party participants are entitled to protect their own communications in the mediation. ${ }^{83}$ The privilege applies unless waived ${ }^{84}$ precluded by reason of prejudicing another party in a proceeding ${ }^{85}$ or if it fell within one of the exceptions. ${ }^{86}$ The exceptions may be classified into two groups: where societal interest in a mediation communication outweighs the private interest in confidentiality ${ }^{87}$ and where the relative strengths of societal and private interests are to be determined by the court on a case by case basis. ${ }^{88}$ Unless agreed to the contrary, the privilege extends to international commercial mediation, overriding the narrower scope of evidentiary exclusions under article 10 of the UNCITRAL Model Law on International Commercial Conciliation. ${ }^{89}$

77 The National Conference of Commissions on Uniform State Laws approved and recommended for enactment the Uniform Mediation Act in all states in August 2001: <http://www.law.upenn.edu/bll/archives/ulc/mediat/2003finaldraft.htm> accessed 8 April 2010. As of December 2009, 11 states adopted the Act. They are: District of Columbia, Idaho, Illinois, Iowa, Nebraska, New Jersey, Ohio, South Dakota, Utah, Vermont and Washington: <http://www.mwi.org/uma/> accessed 8 April 2010.

78 Uniform Mediation Act, above n. 77 at s. 2(2).

79 Ibid., Prefatory Note and Comments to section 4.

80 Ibid. at s. 4(a).

$81 \mathrm{Ibid}$. at s. 2(7).

82 Ibid. at s. 4(b)(1), (2).

83 Ibid. at s. 4(b)(2), (3).

$84 \mathrm{Ibid}$. at s. $5(\mathrm{a})$

85 Ibid. at s. 5(b)

86 Ibid. at s. 6.

$87 \mathrm{Ibid}$. at s. 6(a). No privilege attaches to a mediation communication which is a signed mediated agreement, a public document, a threat of bodily harm or violent crime, a plan to commit or conceal criminal activity, the response to a claim of misconduct or malpractice of a mediator or a mediation participant, and evidence related to abuse, neglect, abandonment or exploitation in child or adult protection proceedings.

$88 \mathrm{Ibid}$. at s. 6(b). Where a mediation communication is proposed to be used in a criminal proceeding or in challenging the mediated agreement, the court may hold an in camera evidentiary hearing and allow disclosure if the need for the evidence substantially outweighs the interest in protecting confidentiality under the facts and circumstances of the particular case.

89 Ibid. at s. 11. 
A similar development has been gaining currency in European law. The Mediation Directive ${ }^{90}$ sets out five measures ${ }^{91}$ to encourage the use of mediation in cross-border disputes, ${ }^{92}$ one of which is a mediator's privilege. Article $7(1)$ provides that mediators can refuse to testify in judicial proceedings or arbitration regarding any information arising out of or in connection with a mediation process, unless the parties agree, overriding considerations of public policy arise, or the disclosure is necessary in order to implement or enforce a concluded agreement. The qualified protection for mediation confidentiality is also based on empirical assumptions that confidentiality is important ${ }^{93}$ and fosters full and meaningful communications. ${ }^{94}$ The Directive does not only guarantee the minimum level of confidentiality in cross-border mediation, ${ }^{95}$ but it also stimulates parallel protection at the domestic level.

\section{Conclusion}

Settlement of disputes has become all the more important in the reformed civil justice system in Hong Kong. The current legal framework promotes the prospects of settlement by maintaining confidentiality in settlement negotiations at common law. Obligations of confidentiality, legal professional privilege and the without prejudice rule provide confidentiality in mediation communications. But recent first instance decisions in England and Wales show that these principles do not confer a blanket right to shield mediation communications in subsequent proceedings.

Various local institutions put efforts to assure confidentiality in mediation as part of their drive to facilitate the greater use of this alternative dispute resolution procedure. Unfortunately, leading mediation service providers failed to reflect the scope and limits of the common law principles in the internal rules. The judiciary did not take up the challenge to clarify areas of uncertainty at common law. The government has sensibly recommended the enactment of specific legislation on mediation, but it must grasp this opportunity to provide further legal protection for mediation confidentiality. In order to maintain Hong Kong's harmonious community and its status as a leading financial and business centre, the proposed mediation ordinance should adopt comprehensive sanctions for breach of confidentiality and an appropriate form of mediation privilege.

90 Directive 2008/52/EC of the European Parliament and of the Council of 21 May

2008 on certain aspects of mediation in civil and commercial matters (the

Mediation Directive) [2008] OJ L163/3.

91 Mediation Directive, above n. 90 at arts $4-8$.

$92 \mathrm{lbid}$. at art. 1.

93 Ibid., recital 23.

94 Commission (EC), 'Alternative dispute resolution in civil and commercial law' (Green Paper) COM (2002) 196 final, 19 April 2002, para. 79.

95 Mediation Directive, above n. 90, recital 23, art. 7(2). 